\title{
Contribution to the Eco-Palynological Studies of Wadi El Natron, Egypt
}

\section{Azzazy MF ${ }^{1 *}$ and Marco AVC $^{2}$}

${ }^{1}$ Surveys of Natural Resources Department, University of Sadat City, Egypt

${ }^{2}$ Postgraduate Interuniversity School in Human Evolution, University of Burgos, Burgos, Spain

*Corresponding author: Mohamed Fathi Azzazi, Surveys of Natural Resources Department,

Research Article

Volume 3 Issue 1

Received Date: December 05, 2019

Published Date: February 14, 2020 Environmental Studies and Research Institute, University of Sadat City, Egypt; Email: mohamed.azzazy@esri.usc.edu.eg

\section{Abstract}

Palynological study of three soil profiles has been carried out from the Wadi El-Natrun area, Western Desert of Egypt for their pollen content dating Late Pliocene to present. Results revealed predominance of Mangroves vegetation Avicennia marina during Late Pliocene, and, Early Pleistocene. A warm humid climate with intermittent dry periods is indicated from the Late Pliocene recorded fossils. Fossil remains of Juncus and Salsola pollen types. Lycopodium spores, Pinus and Concentricystes spores were recorded during Late Pliocene and Holocene, Early Pleistocene which suggest a humid and warm climate at this period. The climate was warm arid alternating with warm humid and sometimes cool-temperate rainy periods as indicated by the presence of grasess (Poaceae) and (conifer, Pinus). Swamp elements, Typha and phragmites pollen types were recorded with high percentage indicating a swampy habitat during Holocene period. The present vegetation cover of the studied area represented by 27 species belonging to 12 families, 4 annuals and 23 perennial plants and a few individuals of Acacia, Tamarix type the most dominant shrubs, followed by associate types e.g halophytes Salsola, Zygophyllum, Cornulaca and few of annuals Senecio and Sonchus which represent mesophytic species, while the differences in vegetation of present and old may due to the environmental and climatic changes. In the present, the rising salinity and high nutrient loading due to human activities has allowed for the growth of the halophytic community. So, Palynological investigations may be used to detect the effects of climatic changes on terrestrial plant vegetation and as additional tool to predict the past climatic changes.

Keywords: Wadi El Natrun; Palynology; Climatic Changes; Palaeovegetation; Pliocene; Palaeoenvironment

\section{Introduction}

Wadi El-Natroun is a narrow depression located in the west of the Nile Delta, approximately $110 \mathrm{~km}$ northwest of Cairo between longitudes, 30 $02^{\prime}$ and 30 ${ }^{\circ} 29^{\prime} \mathrm{E}$ and latitudes, $30^{\circ} 16^{\prime}$ and $30^{\circ} 32^{\prime} \mathrm{N}$ (Figure 1). The total area of Wadi El Natrun is $281.7 \mathrm{Km} 2$, extended in a NW-SE direction and $23 \mathrm{~m}$ below sea level. The underground water origin is seepage from the Nile stream, due to its proximity and low level [1]. Wadi El Natrun area considered as an extremely arid region where the mean annual rainfall, evaporation and temperature are $41.4 \mathrm{~mm}, 114.3 \mathrm{~mm}$ and $21^{\circ} \mathrm{C}$ respectively [2]. The saline lands are widely distributed globally and constitute about $10 \%$ of the Earth's terrestrial surface OLeary and Glenn, Zahran $[3,4]$ reported that the inland salt marshes of the Egypt's Western Desert are found in the form of Sabkhas around the lakes, springs and wells of the oases, e.g, Wadi El-Natrun, and El-Faiyum. Flora of Egypt comprises 2.085 species, 130 families and 722 genera of which 1.095 species grow in the Mediterranean region [5]. According to 


\section{International Journal of Paleobiology \& Paleontology}

Appelgren [6] vegetation has been widely used to describe habitat characteristics [7]. Kassas Stated that, in Egypt, desert vegetation is the most important and characteristic type of natural plant life, also Abd El Ghani, et al. [8] stated that vegetation covers vast area and formed mainly of xerophytic shrubs and sub-shrubs. Palynology is the study of pollen grains produced by seed plants (angiosperms and gymnosperms) and spores produced by pteridophytes, bryophytes, algae and fungi [9]. Palynology serves as a tool for reconstruction of past vegetation and environment. It can also be applied to taxonomy, genetics, evolutionary studies, honey studies, forensic sciences, and allergy studies, tracing vegetation history in individual species and in communities, climate change studies and study of past human impact on vegetation [10]. Pollen analyses provided information on the regional and local vegetation history [11]. One of the aims of palynological studies is the recognition of vegetation and plant communities on the basis of associated pollen grains.

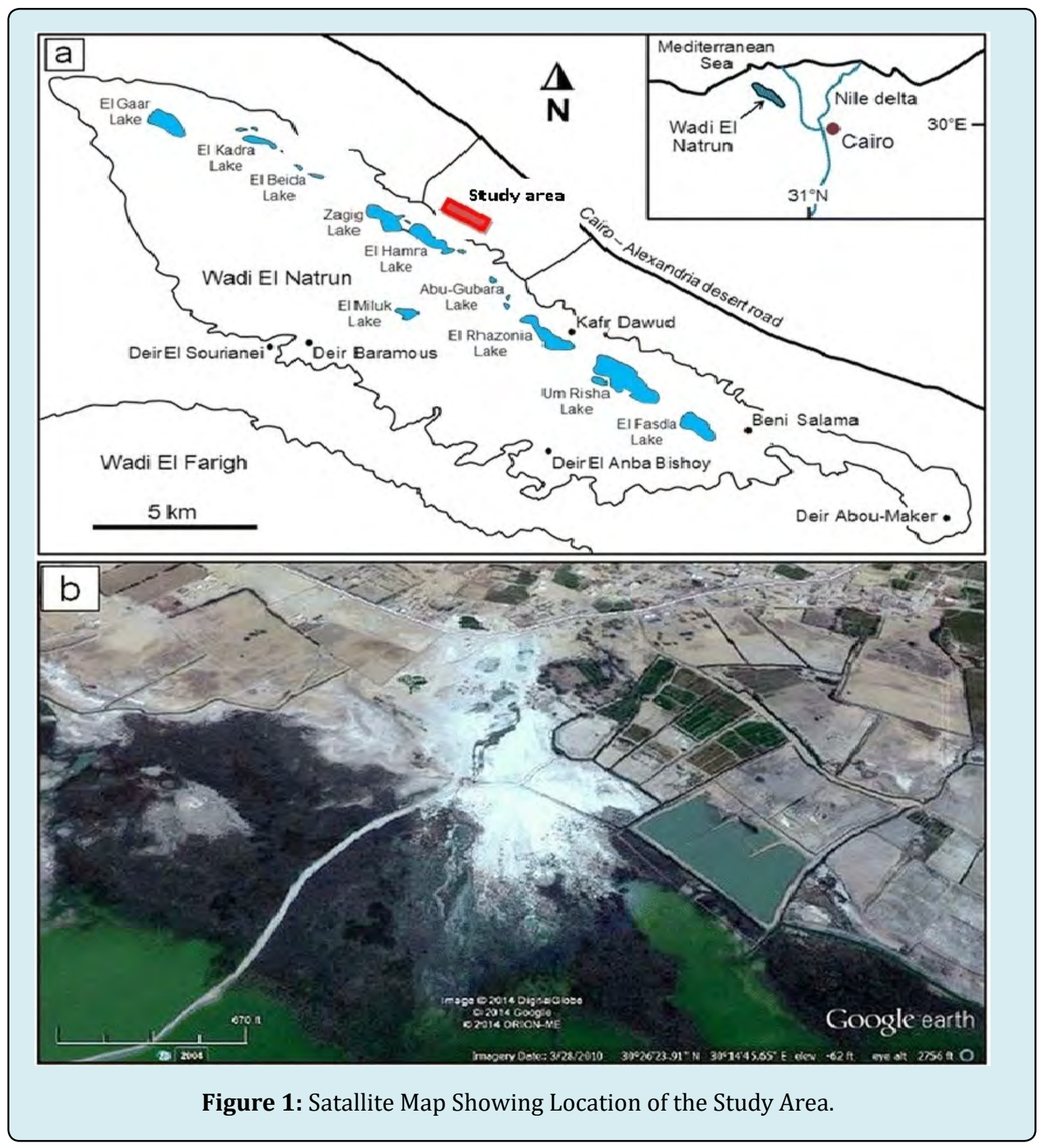

Climate change is often invoked as a trigger for the collapse of civilizations. The fall of the Akkadian Empire and the end of the Egyptian Old Kingdom around 4,200 years BP have both been attributed to climatic change resulting in regional desiccation [12,13]. Dating of archaeological sites, lake sediments and faunal remains indicates that wet conditions were established in the Sahara by around 10,000 $\mathrm{BP}$ after a long period of aridity associated with the last glacial period $[14,15]$. The main objective of this investigation was to study Wadi El Natrun in the western desert sector of Egypt 


\section{International Journal of Paleobiology \& Paleontology}

through surveying present vegetation cover of Wadi El Natrun area and by comparing between present and old vegetation of Wadi El Natrunarea, reconstructing past vegetation covers and the response of dry and wet ecosystems to changes in regional climate based on palynological investigation of fossil pollen data.

\section{Study Area}

\section{Geology and Geomorphology}

Wadi El Natrun is one of the three sub-basins that compose the large circular depression of Western Desert. Wadi EL-Natrun area is one of the promising areas in the Western Desert for reclamation and utilization due to its location and the presence of ground water in a suitable quality for irrigation. It is located in the northeast corner of the Western Desert between longitudes $30^{\circ} 00$ and $30^{\circ} 30$ East, and latitudes $30^{\circ} 15^{\prime}$ and $30^{\circ} 30^{\prime}$ North (Figure 1). Wadi El Natrun Depression has an oval shaped, with about $50 \mathrm{~km}$ in length and the width ranges from 15 to $20 \mathrm{~km}$. The total area of the depression that lies below sea level (0-23 m BSL) is about 50000 hectares and the climate hot deserts.

\section{Geology of Wadi EL-Natrun}

Geology of Wadi El-Natrun was studied by many authors e.g. (Beadnell, Said, and Hendriks, et al.) [16-18]. In Wadi ELNatrun depression, the surface is underlain by both Tertiary and Quaternary sediments with local outcrops of basalt and diorite (Figure 2). These rocks display different litho faces (sand, gravel condition). The surface sandstone and clay limestone etc belonging to different geological environments are rather simple while the subsurface structures are very complicated.

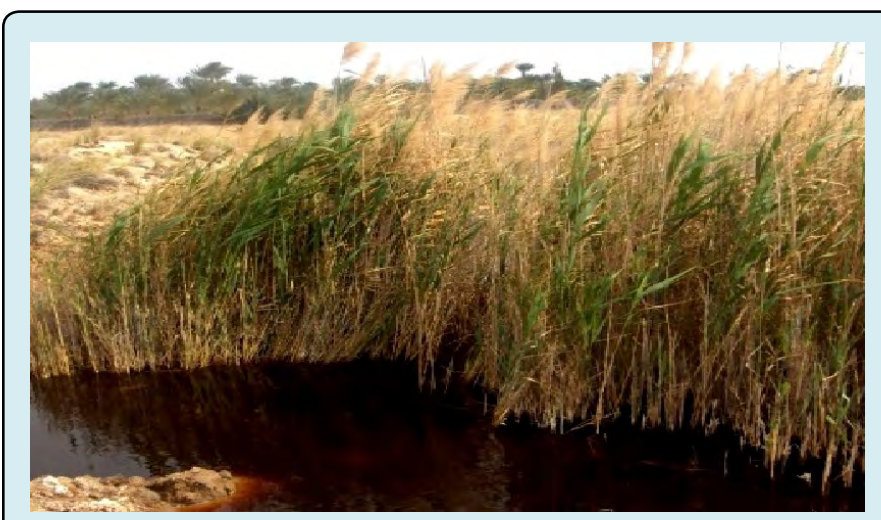

Figure 2: Phragmites community in red water dominated with Phragmites austoralis

\section{El Hamra Lake}

El-Hamra Lake, Wadi El-Natrun depression, Beheira,
Egypt, Quaternary, Cenozoic sedimentary rocks, Age: Pleistocene (0-2.588 Ma), Lithology: Sandstone-siltstone. Hamra Lake connected by a small canal in the northwestern end of Zug Lake (Figure 1).

\section{Pliocene}

Wadi EL-Natrun area, the Pliocene dominated by shallow marine and brackish water deposits which overlain by Nilotic sands and gravel (Pleistocene) and underlain by a thick sandy section belonging to unconformable to lower Miocene Moghar Formation [19].

\section{Wadi EL Natrun Formation}

The effect of late Pliocene pluvial in southern Egypt was the convert of the Nile Valley gulf into a channel of a master stream; Paleo-Nile [20] and also reported that Wadi EINatrun depression was subjected to considerable lowering during the early Pleistocene arid climate. Sediments are largely restricted to the depression area developed into gypseous clays and sands of typical brackish water origin. The portion of Pliocene was distinct into two series, i.e., an upper (El Mulok) dominated with halophytic vegetation and a lower series (Beni Salama) halophytic and mesophytic vegetation.

\section{Salt Lakes and Sabkhas}

Wadi El Natrun depression is occupied by a series of saltwater lakes, which are the lowest elevation in the depression and is usually occupied by saline water (Figure 2). Most important lakes are from northwest to southeast; El-Gaar, Khadra, El-Beida, El-Saad, El-Hamra, Gabboura, El-Rasoneya. The saline lakes receive saline water from the underlying groundwater through the faults and joints. The level of water in these lakes is fluctuated seasonally, becoming higher in the autumn and the winter and lower in the spring and the summer. This is much related to the general fluctuation of the groundwater table and the variation of the evaporation rate. The saline waters in these lakes are rich in Natrun and halite salts. The salt marches occupy the area between and around the salt lakes. The surface of these marches is covered with sabkha consisting of crystalline gypsum, sand and clay with some calcareous materials [21].

\section{Materials and Methods}

The present vegetation analysis was carried out on six community types representing the vegetation of the study area at El Hamra site. In each community, 5 stands $(20 \mathrm{~m} \mathrm{x}$ $20 \mathrm{~m})^{2}$ were studied for each community type. Determining the dominant plants and visual estimate (using stand method for plants counting to determine the dominants and associates species according to references methods listed 


\section{International Journal of Paleobiology \& Paleontology}

in this paper) of the total cover and the individual cover of each species percentage dominance and abundance scale following Braun [22]. Each stand group representing a habitat type, the dominant species, community associates, number of individuals, abundance percentage were recorded and calculated according to Misra [23]. The vegetation analysis, floristic composition were carried out according to Hanson, et al. and Kershaw [24,25]. Within each stand, plant species were recorded. Taxonomic nomenclature followed Tackholm [5], updated with Boulus [26,27]. Plant cover was estimated quantitavely by the line intercept method (Canfield 1941), Indices of halophytism (IH) and xerophytism (IX) are obtained according to the equations:

$$
I H=\frac{H \times 100}{T}, I X=\frac{H \times 100}{T}
$$

Abundance : ab $\%=\frac{\text { No. individuals of a given species } X 100}{\text { Total No. of all individuals }}$

Soil samples representing each community type were collected from exposed surfaces of $20 \mathrm{~cm}$, deep profiles. The samples were air-dried and mixed. The soil characteristics were determined using the methods described by Pansu, et al. and Margesin, et al. [28,29].

\section{Sample Collection for Pollen Analysis}

Three soil cores were done to $15 \mathrm{~m}$ depth in different localities at study area (Figure 3). 5gm soil was sampled every $125 \mathrm{~cm}$ of each soil core for pollen analysis. Samples were macerated following the technique of Erdtman [30]. Soil samples were treated with $10 \% \mathrm{KOH}$ solution to deflocculate the matrix then washed several times with water after which it was passed through a sieve. The filtrate was transferred in polythene jars and treated with $40 \% \mathrm{HF}$ for at least 6-7 days to dissolve silica. After decanting the $\mathrm{HF}$, the material was then washed with water several times until the sample was free of Acid and then the residue was acetolysed by standard acetolysis method using acetolysis mixture (9:1, acetic anhydride and conc. sulphuric acid). The processed samples for microscopic observation were stored in 50\% Glycerine with few phenol drops to avoid microbial contamination. A Lycopodium tracer was added to calculate pollen concentration (grains/cm. Pollen analysis, identification routinely used $\mathrm{x} 400$ magnification with $\mathrm{x} 1000$ magnification for small and difficult types with reference to standard keys [31,32] and the reference collection key pollen of Environmental Studies and Research Institute Minufiya University (ESRI). Pollen identified to the lowest taxonomic level possible with reference collections, atlases e.g, Moore [33], and other publications [34]. Pollen grains that were broken, corroded, hidden or otherwise damaged were counted as 'Indeterminate', and those that were unidentifiable were counted as 'Unknown.

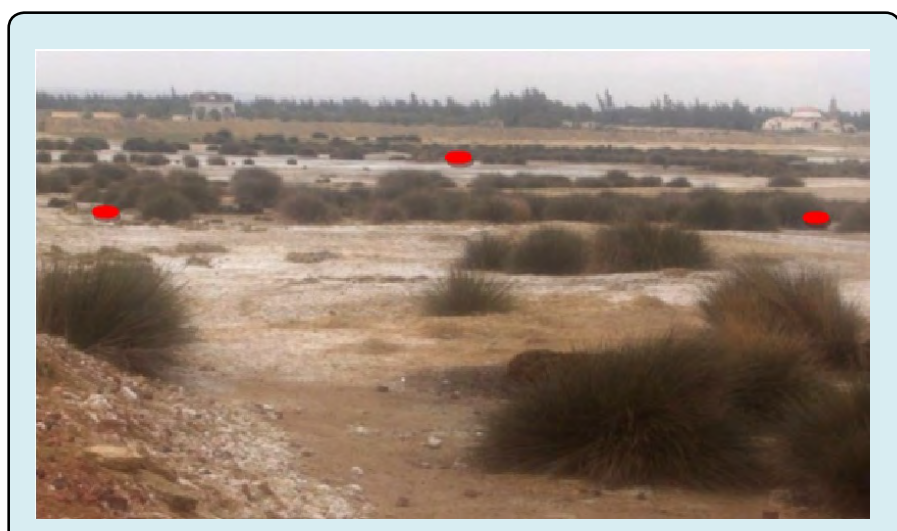

Figure 3: Locations of the studied profiles at Wadi el Natrun West Nile Delta.

\section{Chronology and Dating}

Radiocarbon datings obtained through correlation with the sedimentary layers on the basis of archaeological findings regarding such other archaeological antiquities considered markers of age. Chronology of soil strata was obtained by Austrian Mission for archaeological excavations in Egypt.

\section{Pollen Analysis}

Pollen samples were prepared using $10 \%$ Napyrophosphate, sieving using 200-300 $\mu \mathrm{m}$ and $7 \mu \mathrm{m}$ meshes, $10 \% \mathrm{HCl}$, acetolysis, heavy liquid separation (Na meta tungstate hydrate with specific gravity of 2.0 and centrifugation at $2000 \mathrm{rpm}$ for 20 minutes), $40 \%$ $\mathrm{HF}$, and mounting with glycerol jelly on permanent slides according to Faegri, et al. [35]. While Lycopodium spores were used to calculate pollen concentration (pollen grains per $/$ gram $=\mathrm{p} / \mathrm{g}$ ), and pollen analyses were performed at $400 \times$ and $1000 \times$ with immersion oil light microscopy for determinations. The pollen terminology followed Hesse, et al. [36]. Photomicrographs of fossil pollen were taken, difficult to identify pollen were sent to Professor Sekena Ayyad, Botanical Institute of the Bergen University Norway, for identification. 


\section{Results}

\section{Current Climate of the Study Area}

\begin{tabular}{|c|c|c|c|c|c|}
\hline $\begin{array}{c}\text { Climatic factors/ } \\
\text { Months }\end{array}$ & $\begin{array}{c}\text { Rainfall } \\
(\mathbf{m m})\end{array}$ & Temperature(C) & $\begin{array}{c}\text { Relative } \\
\text { humidity (\%) }\end{array}$ & $\begin{array}{c}\text { Evaporation (mm/ } \\
\text { day) }\end{array}$ & $\begin{array}{c}\text { Wind velocity } \\
\text { (km/hr) }\end{array}$ \\
\hline January & 10 & 16 & 57 & 2.7 & 10 \\
\hline February & 8.1 & 18 & 55 & 2.9 & 10.5 \\
\hline March & 4.1 & 25 & 45 & 3.4 & 11.8 \\
\hline April & 1 & 29 & 48.2 & 4.4 & 12 \\
\hline May & 0 & 33.5 & 50 & 5.1 & 10.1 \\
\hline June & 0 & 36 & 52 & 5.5 & 10.5 \\
\hline July & 0 & 37 & 56 & 4.8 & 10.3 \\
\hline August & 0 & 38 & 57 & 4.7 & 8.7 \\
\hline September & 0 & 33 & 58 & 4.2 & 8.5 \\
\hline October & 1.2 & 27.5 & 58.2 & 4 & 8.9 \\
\hline November & 2.1 & 25 & 56.1 & 3.3 & 9.6 \\
\hline December & 9.3 & 22 & 55 & 2.8 & 10.1 \\
\hline
\end{tabular}

Table 1: Mean Values of Climate of Wadi El Natrun (from 2014-2019).

Meteorological data recorded at local weather stations for the period (2014-2019) showed annual mean rainfall of $10 \mathrm{~mm}$ January to no rainfall in May to September, annual mean temperature of varied from $38.0^{\circ} \mathrm{C}$ in August to $16.0^{\circ} \mathrm{C}$ in January, while annual mean relative humidity ranging from $58.2 \%$ in October to $45 \%$ in March. Evaporation annual mean varied from $5.5 \mathrm{~mm} /$ day June to $2.7 \mathrm{~mm} /$ day January. Wind velocity annual mean varied from $12 \mathrm{~km} / \mathrm{h}$ in April to $8.5 \mathrm{~km} / \mathrm{h}$ in September (Table 1).

\section{Physical and Chemical Analysis of Soil Profiles}

\begin{tabular}{|c|c|c|c|c|c|c|}
\hline \multicolumn{7}{|c|}{ Plant Communities } \\
\hline Soil characters (\%) & $\begin{array}{c}\text { Cornulaca } \\
\text { monocantha }\end{array}$ & $\begin{array}{c}\text { Cyperus } \\
\text { lavegatus }\end{array}$ & $\begin{array}{c}\text { Phragmites } \\
\text { austoralis }\end{array}$ & $\begin{array}{c}\text { Desmostachya } \\
\text { bipinnata }\end{array}$ & $\begin{array}{c}\text { Salsola } \\
\text { impricata }\end{array}$ & $\begin{array}{c}\text { Tamarix } \\
\text { aphylla }\end{array}$ \\
\hline Gravel $(>2.057 \mathrm{~mm})$ & $0.32 \pm 0.03$ & $0.54 \pm 0.09$ & $0.22 \pm 0.03$ & $0.27 \pm 0.05$ & $0.06 \pm 0.06$ & $0.04 \pm 0.00$ \\
\hline Coarse sand $(2.057-1.003 \mathrm{~mm})$ & $6.73 \pm 3.81$ & $11.41 \pm 3.35$ & $6.09 \pm 2.47$ & $6.15 \pm 0.09$ & $6.36 \pm 1.45$ & $5.60 \pm 1.44$ \\
\hline Median sand $(1.003-0.500 \mathrm{~mm})$ & $11.38 \pm 3.41$ & $10.26 \pm 2.45$ & $5.88 \pm 2.40$ & $4.46 \pm 1.23$ & $5.10 \pm 1.85$ & $5.55 \pm 1.13$ \\
\hline Fine sand (0.500-0.211 mm) & $33.61 \pm 7.12$ & $23.90 \pm 3.36$ & $35.35 \pm 6.89$ & $34.05 \pm 3.53$ & $30.69 \pm 4.04$ & $27.17 \pm 3.95$ \\
\hline Very fine sand (0.211-0.104 mm) & $31.74 \pm 4.94$ & $36.10 \pm 9.80$ & $32.22 \pm 5.94$ & $40.10 \pm 4.40$ & $37.41 \pm 5.57$ & $35.50 \pm 1.28$ \\
\hline Silt (0.104-0.053 mm) & $10.30 \pm 3.20$ & $8.94 \pm 4.45$ & $13.74 \pm 5.83$ & $14.52 \pm 1.56$ & $13.65 \pm 2.57$ & $14.60 \pm 2.29$ \\
\hline Clay (<0.053 mm) & $3.23 \pm 1.98$ & $3.56 \pm 1.31$ & $5.91 \pm 1.65$ & $4.53 \pm 0.94$ & $4.31 \pm 0.71$ & $5.25 \pm 1.19$ \\
\hline Moisture content & $5.70 \pm 2.20$ & $8.10 \pm 0.51$ & $6.30 \pm 0.10$ & $6.60 \pm 0.80$ & $3.30 \pm 0.30$ & $3.50 \pm 0.30$ \\
\hline Porosity & $35.80 \pm 5.20$ & $44.60 \pm 5.40$ & $40.50 \pm 3.50$ & $42.40 \pm 3.50$ & $40.90 \pm 3.70$ & $40.50 \pm 3.90$ \\
\hline WHC & $36.90 \pm 2.20$ & $43.50 \pm 3.70$ & $42.50 \pm 2.00$ & $41.60 \pm 7.50$ & $37.10 \pm 5.00$ & $38.70 \pm 4.50$ \\
\hline Organic carbon & $0.60 \pm 0.40$ & $1.50 \pm 0.30$ & $0.70 \pm 0.30$ & $0.30 \pm 0.10$ & $0.70 \pm 0.10$ & $0.80 \pm 0.10$ \\
\hline CaCO & $6.70 \pm 2.20$ & $10.50 \pm 3.50$ & $11.50 \pm 4.60$ & $7.50 \pm 1.80$ & $8.50 \pm 1.20$ & $7.20 \pm 1.50$ \\
\hline TSS & $2.50 \pm 0.80$ & $1.50 \pm 0.40$ & $2.50 \pm 0.30$ & $2.80 \pm 0.20$ & $2.40 \pm 0.10$ & $2.60 \pm 0.10$ \\
\hline Chlorides (ClG) & $0.09 \pm 0.03$ & $0.11 \pm 0.08$ & $0.10 \pm 0.03$ & $0.06 \pm 0.01$ & $0.02 \pm 0.01$ & $0.31 \pm 0.02$ \\
\hline
\end{tabular}


International Journal of Paleobiology \& Paleontology

\begin{tabular}{|c|c|c|c|c|c|c|}
\hline Sulphate $\left(\mathrm{SO}_{4} !\right)$ & $0.21 \pm 0.01$ & $0.41 \pm 0.05$ & $0.25 \pm 0.05$ & $0.17 \pm 0.09$ & $0.11 \pm 0.03$ & $0.28 \pm 0.06$ \\
\hline Carbonates $\left(\mathrm{CO}_{3} \mathrm{G}\right)$ & $0.00 \pm 0.00$ & $0.00 \pm 0.00$ & $0.00 \pm 0.00$ & $0.00 \pm 0.00$ & $0.00 \pm 0.00$ & $0.00 \pm 0.00$ \\
\hline Bicarbonates $\left(\mathrm{HCO}_{3} \mathrm{G}\right)$ & $0.09 \pm 0.04$ & $0.10 \pm 0.05$ & $0.11 \pm 0.04$ & $0.03 \pm 0.01$ & $0.14 \pm 0.05$ & $0.14 \pm 0.04$ \\
\hline $\mathrm{pH}$ & $8.30 \pm 0.30$ & $8.20 \pm 0.50$ & $8.00 \pm 0.50$ & $7.80 \pm 0.10$ & $7.70 \pm 0.30$ & $8.50 \pm 0.30$ \\
\hline
\end{tabular}

Table 2: Mean values of physical and chemical characters of soil samples of the various community types.

\section{Soil Analysis of Present Vegetation Cover}

Cyperus Lavegatus: Data in Table 2 showed clearly that, the mechanical analysis of the soil samples adjusting this community types revealed the highest percentage of soil particles was very fine sand (mean $31.74 \pm 4.94$ ). The percentage of silt was high mean value $(10.30 \pm 3.20 \%)$. The soil moisture content was generally low with mean value of $(5.70 \pm 2.20 \%)$. The total soluble salt content was low and attained mean value of $(2.5 \pm 0.80 \%)$.

Phragmites Austoralis: The very fine sand (class 0.211$0.104 \mathrm{~mm})$ recorded mean value $(36.10 \pm 9.80 \%)$. The soil moisture content was relatively high (mean $8.10 \pm 0.51 \%$ ). The soil pore-spaces attained high value (mean $44.60 \pm 5.40 \%)$. The soil salinity was moderate with mean value $(1.50 \pm 0.40 \%)$.

Desmostachya Bipinnata: Table 2 shows the soil of Desmostachya bipinnata is mainly sandy with predominance of fine sand value mean $(35.35 \pm 6.89 \%)$. The silt and clay particles are poorly represented. The soil moisture shows a wide range of variation and attained mean value of $(6.30 \pm 0.10 \%)$. The soil pore-species reached mean value of $(40.50 \pm 3.50 \%)$, while total soluble salt content mean value $(2.50 \pm 0.30 \%)$.

Salsola Impricata: Data in Table 2 showed clearly that, the mechanical analysis of the soil samples adjusting this community types revealed the highest percentage of soil particles was very fine sand $(40.10 \pm 4.40 \%)$. The percentage of silt was high $(14.52 \pm 1.56 \%)$. The soil moisture content was generally low with mean value of $(6.60 \pm 0.80 \%)$. The total soluble salt content was low and attained mean value of $(2.80 \pm 0.20 \%)$.

Tamarix Aphylla: The very fine sand recorded mean value (37.41 $\pm 5.57 \%)$. The soil moisture content was relatively high (mean $3.30 \pm 0.30 \%$ ). The soil pore-spaces attained high value (mean $40.90 \pm 3.70 \%$ ). The soil salinity was moderate with mean value $(2.40 \pm 0.10 \%)$.

Cornulaca Monocantha: Data in Table 2 showed clearly that, the mechanical analysis of the soil samples adjusting this community types revealed high percentage of soil particles was very fine sand $(35.50 \pm 1.28 \%)$. The percentage of silt was high (14.60 $\pm 2.29 \%)$. The soil moisture content was generally low with mean value of $(3.50 \pm 0.30 \%)$. The total soluble salt content was low and attained mean value of $(2.60 \pm 0.10 \%)$.

\section{Present Vegetation Cover}

Data in Table 3 showed clearly that, Six community types were recorded; twenty-seven species ( 4 annuals and 23 perennials) belonging to 12 families were recorded in the study area. The most represented families are Poaceae 44.59\%, Chenopodiaceae 38\%, Juncaceae $37 \%$ and Typhaceae $37 \%$. More than half of the species were perennials herbs $(85.18 \%)$ and $14.81 \%$ were annual grasses.

\begin{tabular}{|c|c|c|c|c|}
\hline $\begin{array}{c}\text { Dominant species / } \\
\text { Community }\end{array}$ & Associates & Family & $\begin{array}{c}\text { Number } \\
\text { Individuals }\end{array}$ & Abundance \% \\
\hline \multirow{4}{*}{ Cyperus laevigatus } & Juncus rigidus & Juncaceae & 37 & 37 \\
\cline { 2 - 5 } & Juncus acutus & Juncaceae & 22 & 22 \\
\cline { 2 - 5 } & Phragmites austoralis & Poaceae & 25 & 25 \\
\cline { 2 - 5 } & Typha domingensis & Typhaceae & 16 & 16 \\
\hline \multirow{4}{*}{ Phragmites austoralis } & Juncus rigidus & Juncaceae & 8 & 11.11 \\
\cline { 2 - 5 } & Juncus acutus & Juncaceae & 5 & 37.77 \\
\cline { 2 - 5 } & Typha elephantina & Typhaceae & 17 & 20 \\
\cline { 2 - 5 } & Cyperus laevigatus & Cyperaceae & 9 & 13.33 \\
\cline { 2 - 5 } & Suaeda aegyptiaca & Chenopodiaceae & 6 & \\
\hline
\end{tabular}


International Journal of Paleobiology \& Paleontology

\begin{tabular}{|c|c|c|c|c|}
\hline \multirow{4}{*}{ Desmostachya bipinnata } & Imperata cylindrical & Poaceae & 35 & 36.45 \\
\hline & Spergularia marina & Caryophyllaceae & 31 & 32.29 \\
\hline & Stipagrostis ciliate & Poaceae & 25 & 26.04 \\
\hline & Pheonix dactylifera & Palmae & 5 & 5.2 \\
\hline \multirow{4}{*}{$\begin{array}{l}\text { Salsola impricata subsp. } \\
\text { Gaetula }\end{array}$} & Cynodon dactylon & Poaceae & 33 & 44.59 \\
\hline & Haloxylon salicornicum & Chenopodiaceae & 9 & 12.16 \\
\hline & Launaea nudicaulis & Asteraceae & 12 & 16.21 \\
\hline & Arthrocnemum macrostachyum & Chenopodiaceae & 6 & 8.1 \\
\hline \multirow{5}{*}{ Tamarix aphylla } & Polypogon monospliensis & Polygonaceae & 13 & 30.95 \\
\hline & Sonchus maritimus & Asteraceae & 12 & 28.57 \\
\hline & Hyoscyamus muticus & Solanaceae & 10 & 23.8 \\
\hline & Pluchea dioscoridis & Asteraceae & 5 & 11.9 \\
\hline & Acacia radiana & Fabaceae & 2 & 4.76 \\
\hline \multirow{4}{*}{ Cornulaca monocantha } & Zygophyllum simplex & Zygophyllaceae & 15 & 30.09 \\
\hline & Sporopolus spicatus & Poaceae & 13 & 29.54 \\
\hline & Panicum turgidum & Poaceae & 9 & 20.45 \\
\hline & Senecio glaucus & Asteraceae & 7 & 15.9 \\
\hline
\end{tabular}

Table 3: Synthetic Characters of Present Vegetation Cover at Wadi El Natrun Study Area.

\section{Palynological Analysis}

Data obtained from (Table 4 \& Figure 4), showed high representation for Concentricystes spores $(15 \%$ Holocene and $11 \%$ recent) at depth $875-1000 \mathrm{~cm}$ and $750-875 \mathrm{~cm}$. Lycopodium spores, recorded 56\% Early Pleistocene about $15200 \pm 1600 \mathrm{BP}$ and $11 \%$ Late Pleistocene about $27.400 \pm$ 600 BP at depth $1000-1125$ and $1250-1375 \mathrm{~cm}$. Pollen spectra are characterized by high percentage values of Pinus $25 \%$ Early Pleistocene about $15200 \pm 1600$ BP and 19\% Late Pleistocene 27.400 $600 \mathrm{BP}$ at depth 1000-1125 and 1250$1375 \mathrm{~cm}$. Typha pollen type recorded $8.9 \%$ Early Pleistocene $15200 \pm 1600 \mathrm{BP}$ and $0.9 \%$ recent at depths $1125-1250 \mathrm{~cm}$ and
$0-125 \mathrm{~cm}$ surface layer. Juncus recorded high representation $12.6 \%$ recent at depth $0-125 \mathrm{~cm}$ surface layer and $12 \%$ Late Pleistocene about $27.400 \pm 600 \mathrm{BP}$ at depth $1250-1375 \mathrm{~cm}$. Poaceae wild grasses recorded $43 \%$ Late Pliocene about $27.400 \pm 600 \mathrm{BP}$ at depth $1250-1375 \mathrm{~cm}$ and $24.6 \%$ recent at depth $0-125 \mathrm{~cm}$. Cyperaceae high representation $14.8 \%$ Early Pleistocene about $15200 \pm 1600 \mathrm{BP}$ at depth $1000-1125 \mathrm{~cm}$ and $1 \%$ recent at depth $0-125 \mathrm{~cm}$, while Chenopodiaceae recorded high representation $51 \%$ recent at $0-125 \mathrm{~cm}$ surface layer and $3.4 \%$ Early Pleistocene $15200 \pm 1600$ BP at depth 1000-1125 cm. Finally, Avicenniaceae pollen type recorded $13 \%$ Late Pliocene $27.400 \pm 600$ BP at depth $1250-1375 \mathrm{~cm}$ and not recorded at the recent layer of the studied core.

\begin{tabular}{|c|c|c|c|c|c|c|c|c|c|c|}
\hline \multirow{2}{*}{ Chronology } & \multirow[t]{2}{*}{ Depth /cm } & \multicolumn{2}{|c|}{ Pteridophyt } & \multirow{2}{*}{$\begin{array}{c}\text { Gym } \\
\text { Pin\% }\end{array}$} & \multicolumn{4}{|c|}{ Monocot } & \multicolumn{2}{|c|}{ Dic } \\
\hline & & Con $\%$ & Lyco\% & & TY\% & JU\% & PO\% & $\mathrm{CY} \%$ & CH\% & Avi\% \\
\hline \multirow{7}{*}{ Recent } & $0-125$ & - & - & & 0.9 & 12.6 & 24.6 & 1 & 51.2 & - \\
\hline & $125-250$ & - & - & - & 0.4 & - & 25 & 2 & 49.8 & - \\
\hline & $250-375$ & - & - & - & 3.4 & 2 & 16.8 & 4 & 36.9 & - \\
\hline & $375-500$ & - & - & - & - & - & 16.3 & 4.7 & 40.5 & - \\
\hline & $500-625$ & - & 0.9 & - & - & - & 7.3 & - & - & - \\
\hline & $625-750$ & 6 & & & & & 9.6 & 5 & - & - \\
\hline & $750-875$ & 11 & - & - & - & - & 3.6 & 7.1 & 20 & - \\
\hline Holocene $7910 \pm 830 \mathrm{BP}$ & $875-1000$ & 15 & - & - & - & - & 24 & - & 5 & 2 \\
\hline
\end{tabular}




\begin{tabular}{|c|c|c|c|c|c|c|c|c|c|c|}
\hline \multirow{2}{*}{$\begin{array}{c}\text { Early Pleistocene } \\
15200 \pm 1600 \mathrm{BP}\end{array}$} & $1000-1125$ & 2 & 56 & 25 & 7 & 10.2 & 32 & 14.8 & 3.4 & 8 \\
\hline & $1125-1250$ & - & 10.4 & 20 & 8.9 & 7.6 & 37.2 & 10.5 & 5.2 & 11 \\
\hline \multirow{2}{*}{$\begin{array}{l}\text { Late Pliocene } 27.400 \pm \\
600 \mathrm{BP}\end{array}$} & $1250--1375$ & - & 11 & 19 & 3.1 & 12 & 43 & - & 16.5 & 13 \\
\hline & $1375-1500$ & - & 5 & - & 0.9 & 8 & 39.7 & - & 12.3 & 9 \\
\hline
\end{tabular}

Table 4: Relative abundance of different pollen and spore types in five grams soil at different depths of Wadi El Natrun profile. Con=Concentricystes; Lyc= Lycopodium; Gym = Gymnospermae; Pin = Pinus; Mon = Monocotyledonae $; \mathrm{TY}=$ Typhaceae; $\mathrm{JU}=$ Juncaceae; PO = Poaceae (Graminae); CY= Cyperaceae; Dic = Dicotolydonae; $\mathrm{CH}=$ Chenopodiaceae; Avi = Avicenniaceae

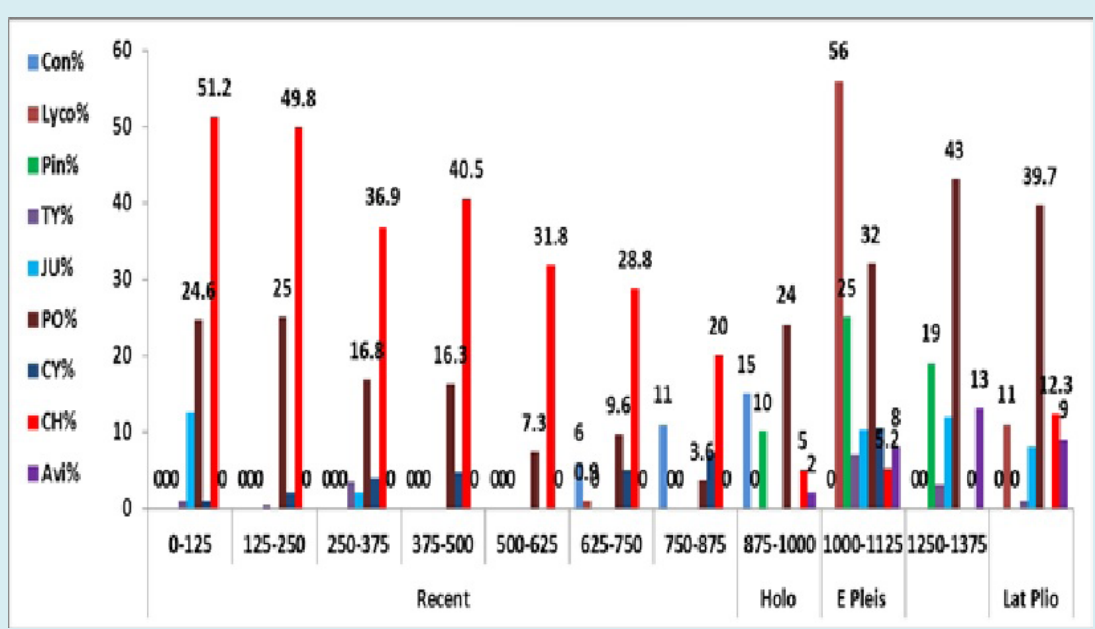

Figure 4: Pollen diagram showing relative abundance of pollen grains extracted from soil profile at Wadi El Natrun.

Pollen diagram showing relative abundance of pollen grains extracted from soil profile at Wadi El Natrun. Holo=Holocene; E Pleis= Early Pleistocene; Lat plio= Late Pliocene); Con = Concentricystes; Lyc= Lycopodium; Pin = Pinus; TY= Typhaceae; JU= Juncaceae; PO = Poaceae Graminae; $\mathrm{CY}=$ Cyperaceae; $\mathrm{CH}$ = Chenopodiaceae; Avi = Avicenniaceae.
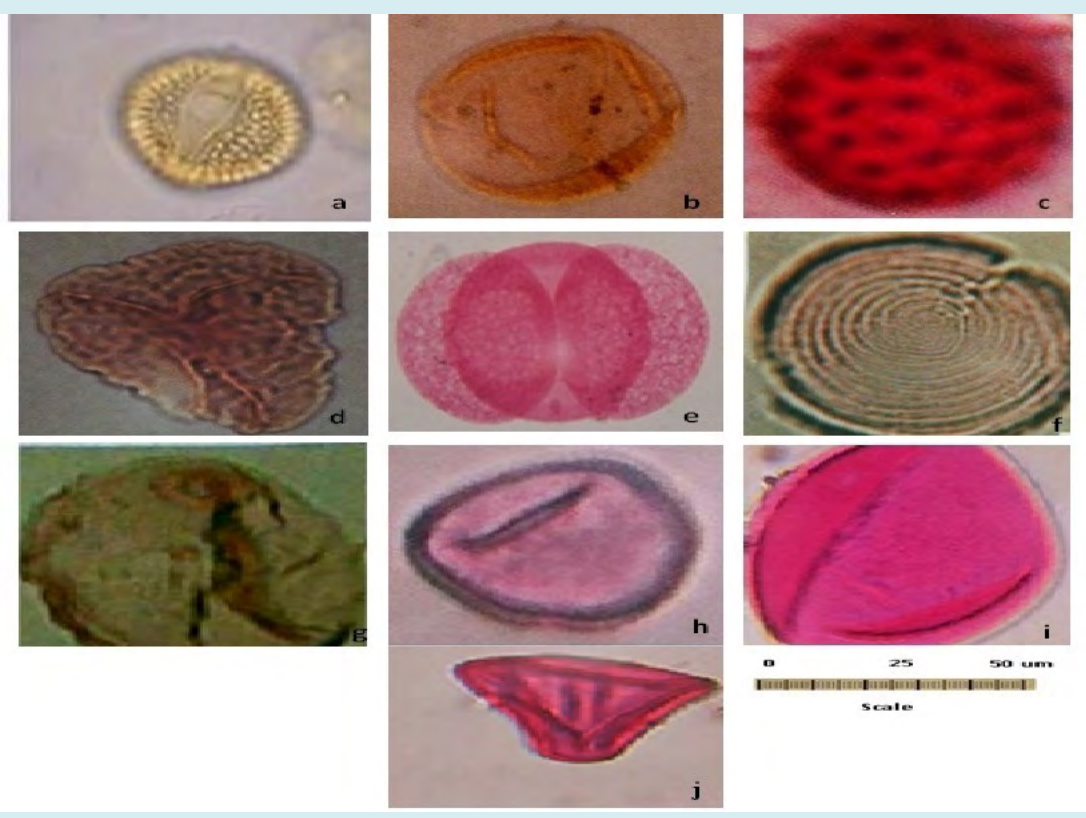

Figure 5: Representative photomicrographs ( $\mathrm{x}=1000$ magnification power) of pollen spores.

(a) Avicennia type 45um, (b) Juncus type $32 \mathrm{um}$, (c) Salsola type 45um, (d) Lycopodium spore $50 \mathrm{um}$, (e) Pinus type 50 um, (f) Concentricystes spore 42um, (g) wild grasses 28, (h) Typha type 39um, (i) Phragmites type 36um, (j) Cyperus type 24 um. 


\section{International Journal of Paleobiology \& Paleontology}

\section{Pollen Description}

- Avicennia Pollen Type: Circular, prolate, aperture tricolpate, reticulate sculpture, size $21 \mathrm{um}$.

- Juncus Pollen Type: Spheroidal shape, radially symmetrical, inaperturate, size $29 \mathrm{um}$.

- Salsola Pollen Type: Spheroidal, polypantoporate, perforate sculpture, $40-45$ pores, grain size (38 um). Lycopodium Spore: Sexine, reticulate sculpture, trilete spore, size 49um.

- Pinus: The grain is known as saccate, sacs similar in size the grain size, 45um, slightly granulate. Concentricystes, Bilaterally symmetrical with fingerprint like concentric, spiral striations on opposite faces, $20-30 \mu \mathrm{m}$

- Wild Grasses: Monoporate, spheroid ovoid shape, porus circular, psilate granulate sculpture, grain size $28 \mathrm{um}$.

- Typha Pollen: Spheroidal, monoporate, micro-reticulate, heterobrochate sculpture, grain size $28 \mathrm{um}$.

- Phragmites Pollen Type: Monoporate, spheroid shape, porus circular, psilate granulate sculpture, grain size 36 um

- Cyperus Pollen: Pear like shape, inaperturate, tectateperforate and psilate sculpture, grain size $24 \mathrm{um}$.

\section{Discussion}

One of the aims of Palynological studies is the reconstruction of palaeoenvironmental changes. From the pollen diagram, information can be obtained about vegetation, floristic composition, climatic changes, lake sedimentation, wind direction, turnover rate of the lake ecosystem and sea levels too West[37]. A study pollen grains and spores, is one important area of research, though we can obtain important information about past plant vegetation, past climate change as well as reconstruct past environment in a given site and geological time.

\section{The Present Climate}

The studied climate (from 2014-2019) has an arid climate, with low and very variable rainfall in winter, a long dry summer, high rates of evaporation, and low humidity. The main wind direction is from the northwest but the ElKhamasin wind (April-May) from the southeast is quite strong and lasts for several days, with considerable effects on precipitation and sand remobilization particularly in the south-western sector.

\section{Present Vegetation}

Plant communities: Vegetation of the surveyed area is organized into units (6 communities). Each of these units is associated with a certain habitat type. Cyperus laevigatus community type: The species assemblage of this community is mixed as it includes both glycophytes and halophytes. This reflects the heterogeneity of the habitat conditions of the plant community and the wide range of ecological amplitude of the dominant species. Teyeb et al. [38] stated that several species of Cyperus laevigatus normally synthesize numerous metabolites in order to adapt to drought stress. Salsola impericata was the common ephemeral. [39].

\section{Soil in Relation to Plant Communities}

Salinity is the most important edaphic factor which affecting distribution and structure of the plant communities, moisture content and fine fractions moreover calcium carbonates also effective $[40,41]$. The Cyperus laevegatus community showed considerable dominant with associated plant species be related to the variation of soil, where soil particles are mainly of very fine sand (mean31.74 $\pm 4.94 \%$ ) silt fraction $10.30 \pm 3.20 \%$, and mean value percentage of clay is $(3.23 \pm 1.98 \%)$. The mean value of moisture content was $3.4 \pm 2.2 \%$. Soil salinity is low (Table 2). Halwagy, et al. reported that the land form of affects the redistribution of rain- water and sediments as secondary effect.

Phragmites austoralis community have high contents of moisture, salinity and silt, where accumulation of deep silt, organic matter, higher contents of moisture and minerals, but low alkalinity prevail [42]. Soil salinity, organic matter, moisture content and fine material were higher in the Juncus, Salsola, Cornulaca Phragmites and Tamarix communities than in any of the other communities. The floristic composition showed dominance of Poaceae, and Chenopodiaceae these families represent the most common in North Africa flora [43].

\section{Palynological Studies}

The aim of this palynological study is the recognition of vegetation and plant communities on the bases of associated pollen grains. Data obtained (Table 4, Figures $4 \& 5$ ) revealed that, Concentricystes spores (Figure 5f) recorded with relative abundance $15 \%$ at Holocene period about $7910 \pm 830$ BP, may suggest that a freshwater body and humid climate was present near the site of the study area, because these type of spores occurs in freshwater and humidity indicators according to Wang, et al. [44] Concentricystes assemblages reflects evergreen Quercus-dominated vegetation, and are indicative of a warm, humid climate in which freshwater lakes or alluvial flats with back-swamps prevailed. While, this findings may support African Humid Period (AHP) is a climate period in Africa during the Holocene during which northern Africa was wetter than today moreover replacement of much of the Sahara desert by grasses, trees and lakes. Later in the 20th century, conclusive evidence of a past greener Sahara, the existence of lakes $[45,46]$ and it was recognized that the Holocene featured a humid period in the Sahara, [47]. Holocene sediments in the Mudanjiang area of Heilongjiang; 


\section{International Journal of Paleobiology \& Paleontology}

Early Pleistocene deposits in Jilin [58]; Lycopodium spores (Figure 5d) has been dominant during Early Pleistocene $15200 \pm 1600$ BP with relative abundance $56 \%$ (Table 4 \& Figure 4), in this connection $[48,49]$ these spores indicate a humid conditions at this period, also recorded in Holocecne Nile Slits from the Nile Delta, [50]. Pinus pollen type (Figure 5e) recorded the highest representation 25\% during Early Pleistocene $15200 \pm 1600 \mathrm{BP}$ and this may indicates warm climate, Hong B [51] stated that the de-glaciation due to a climate warming stage with Pinus percentage increased, Artemisia pollen type percentage decreased and the rapid sea level rise. The pollen analysis indicates that there was a well-established forest around the lake as seen in the high fossil pollen values of Pinus and Avicennia (Figure 5a) 25, $11 \%$ during warm period of Early Pleistocene. However, there was a period of relatively low pollen of forest trees

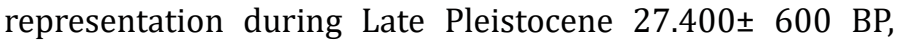
the obvious explanation is a reduction in pollen production caused by a decrease in the flora density of around Wadi El Natrun Lake in response to environmental stress. Cat tail dominated (Typha pollen type Figure 5h) Typhaceae 8.9\% Early Pleistocene $15200 \pm 1600 \mathrm{BP}$, these plants are well known reed swamps which indicates a swampy habitat, according to Ritchie JC and Ayyad SM [52,53]. The Juncus pollen type (Figure $5 \mathrm{~b}$ ) recorded highest representation

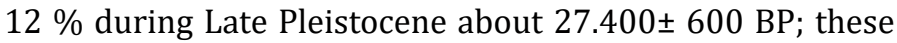
plants are well known as a salt loving or halophytic taxon which suggests an arid environment. In this connection, El Shenbary [54] mentioned that Juncaceae and Chenopodiaceae were salt marsh plants. However, Hydrophytes and rushes (Juncus) suggest the presence of permanent water and marshy habitats [55,56]. Poaceae wild grasses (Figure $5 \mathrm{~g}$ ) recorded the highest representation $43 \%$, dating Late Pleistocene 27.400 600 BP mostly were grasses, which indicates an open, low-diversity savanna with grasses and sedges. Salsola pollen type (Figure $5 \mathrm{c}$ ) belonging to the family Chenopodiaceae xerophytes including salt bushes are significant, indicating that sandy habitats were also present. Cyperus pollen (Figure 5j) reflects significant degree of herbaceous vegetation on the valley floor, and therefore should be included in the pollen sum is best supported, in this connection Ayyad [53] stated that Cyperaceae species were growing in wet or dry places, it is salty or unsalty. There is an increasing in Poaceae and Chenopodiaceae taxa including alophylous shrubs, largely spread in salt-rich soils. Chenopodiaceae pollen type was common and associated with the Poaceae and Cyperaceae. Pollen grains which are blown into lakes can accumulated in the sediments and provide a record of past vegetation Prach [57] Stated that, different types of pollen in lake the sediments reflect the vegetation type that present around this lake, and therefore the climate conditions favorable for that vegetation. So we can conclude that the vegetation indicated by pollen assemblage found in this lower zone of the studied cores is not consistent with the present vegetation found in Wadi El Natrun studied area [58,59].

\section{Conclusion}

We can conclude that, there is a succession climatic changes leads to vegetation successions during the four studied periods, the ecosystems respond sensitively to changes in plant available moisture (precipitation) where the wet habitats forest vegetation and Mangrove were dominant during (Late Pliocene about 27.400 $\pm 600 \mathrm{BP}$ ), followed reed swamps during (Early Pleistocene about $15200 \pm 1600$ BP). The habitats changed to herbaceous vegetation during period (Late Pliocene About 27.400 $600 \mathrm{BP}$ ), while dominance of open vegetation then decrease in humidity, strongly suggesting decrease in precipitation late Pleiostocene. Chenopodiaceae recorded highest abundances 51.2\% recent layer indication to habitat changing to halophytic vegetation, and then changed to mesophytic recent time.

\section{Acknowledgment}

We thank Professors Sekina Ayyad Professor of Palynology and Plant Ecology Mansoura University Faculty of science, Egypt, for helping in our research, providing help for samples collection, identification, chronology, additional feedback, suggestions, and/or comments on the manuscript.

\section{References}

1. Maghraby EMM (1990) Geographical and hydrological studies of Sadat City, Egypt, Thesis Fac Sci, Alexandria University.

2. (2006) Egyptian Meteorological Authority, Cairo, Egypt. International Journal of Meteorology 31(308).

3. Leary OJW, Edward GP (1994) Global distribution and potential for halophytes. Halophytes as a resource for livestock and for rehabilitation of degraded lands 32: 7-15.

4. Zahran MA, Wahid AA (1982) Halophytes and human welfare. Tasks Veg Sci 2: 235-257.

5. Tackholm V (1974) Students flora of Egypt, $2^{\text {nd }}[$ Edn.], Publ Cairo University.

6. Appelgren K, Mattila J (2005) Variation in vegetation communities in shallow bays of the northern Baltic Sea: Aquatic Botany 83(1): 1-13.

7. Kassas M, Girgis WA (1964) Habitat and Plant Communities in the Egyptian Desert: V. The Limestone Plateau J Ecol 52: 107-119. 


\section{International Journal of Paleobiology \& Paleontology}

8. Monier MAG, Amer WM (2003) Soil-vegetation relationships in a coastal desert plain of southern Sinai, Egypt. J Arid Environ 55(4): 607-628.

9. Ali SA (1988) The functional significance of pollen aggregates in angiosperms. Pak J Bot 20: 21-44.

10. Mehwish JN, Mushtaq A, Rehana A, Aulia K, Sadaf P (2004) Palynological Studies of Cultivated Plant Species at University of Arid Agriculture, Rawalpindi, Pakistan. Asian Journal of Plant Sciences 3(4): 476-479.

11. Bennett KD, Willis KJ (2002) Tracking Environmental Change Using Lake Sediments Vol 3: Academic Publishers, Dordrecht, Netherlands.

12. Cullen HM, DeMenocal PB, Hemming S, Hemming G, Brown FH, et al. (2000) Climate Change and the Collapse of the Akkadian Empire: Evidence from the deep sea geology 28: 379-382.

13. Weiss H (1997) Late Third Millennium Abrupt Climate Change and Social Collapse in West Asia and Egypt. Third Millennium BC Climate Change and Old World Collapse pp: 711-723.

14. Goudie A (1992) Environmental Change $3^{\text {rd }}$ [Edn.], Oxford: Oxford University Press.

15. Roberts N (1998) The Holocene: An Environmental History $2^{\text {nd }}$ [Edn.], Oxford: Blackwell Publishers Ltd.

16. Beadnell HJL (1931) “Zerzura”. Geograph J 77: 245-250.

17. Said R (1990) The Geology of Egypt: Elservier Publishing Co, Amsterdam, New York, USA, pp: 734.

18. Hendricks F, Luger P, Kalleribach H, Schroerer JH (1984) Stratigraphical and sedimentological framework of the Kharga-Sinn El-Kaddab Stretch (Western and Southern part of the Upper Nile Basin), Western Desert, Egypt. Berliner Geowise Abh 50: 117-151.

19. El Shahat A, Ayyad SN, Abdalla MA (1997) Pliocene Facies and Fossil Contents of Qaret EI-Muluk Formation at Wadi EI-Natrun Depression, Western Desert, Egypt. Springer-Verlag Facies 37(1): 211-224.

20. Said R (1981) The geological Evolution of the River Nile Heidelberg (Springer) 151: 66.

21. Ismail MM, Gaffar MKA, Azzam MA (2018) Geomorphological Units and Land cover Map of Wadi ElNatrun Area Using Remote Sensing and GIS Techniques, Western Desert, Egypt. Egyptian Journal of Remote Sensing and Space Science 15(1): 39-51.
22. Braun BJ (1965) Plant Sociology: The Study of Plant Communities. Hafner Publ Comp.

23. Misra R (1980) Ecology Workbook: Oxford and IBH. Publ Co, pp: 242.

24. Hanson HC, Churchill ED (1965) The plant community: Reinhold Publishing Corporation.

25. Kershaw KA (1973) An introduction to plant ecology: William Clowes and Sons Ltd London.

26. Boulos L (1995) Flora of Egypt Checklist. Al Hadara Publishing Cairo Egypt, pp: 287.

27. Boulos L (1999) Flora of Egypt. Al Hadara Publishing: Cairo, Egypt 1-4: 419.

28. Pansu M, Gautheyrou J (2006) Handbook of Soil Analysis: Mineralogical, Organic and Inorganic Methods. Springer, pp: 993.

29. Margesin R, Schinner F (2005) Manual for Soil AnalysisMonitoring and Assessing Soil Bioremediation. Springer Science, pp: 366.

30. Erdtman G (1969) Handbook of Palynology-An Introduction to the Study of Pollen Grains and Spores: Munksgaard, Copenhagen, pp: 486.

31. Andrew R (1984) Practical Pollen Guide to the British Flora. QRA, pp: 139.

32. Moore PD, Webb JA, Collinson M (1991) Pollen Analysis $2^{\text {nd }}[$ Edn.], Black well Scientific Publications.

33. Moore PO, Webb JA (1978) An Illustrated Guide to Pollen Analysis: John Wiley and Sons, New York

34. Jarvis DI, Leopold EB, Liu Y (1992) Distinguishing the pollen of deciduous oaks evergreen oaks and certain rosaceous species of southwestern Sichuan Province, China. Review of Palaeobotany and Palynology 75(3-4): 259-271.

35. Faegri K, Kaland PE, Krzywinski K (1989) Textbook of pollen analysis: New York: John Wiley \& Sons.

36. Hesse M, Halbritter H, Weber M, Buchner R, Ulrich S, et al. (2009) Pollen Terminology. An illustrated handbook. Springer Wien New York.

37. WEST RG (1971) Studying the past by pollen analysis. Oxford University Press.

38. Teyeb H, Zanina N, Neffati M, Douk I, Najjar WMF (2012) Cytotoxic and antibacterial activities of leaf extracts of Astragalus gombiformis Pomel (Fabaceae) growing wild 


\section{International Journal of Paleobiology \& Paleontology}

in Tunisia. Turk J Biol 36: 53-58.

39. Boulos L (2009) Flora of Egypt checklist. Revised annotated Cairo, Al Hadara Publishing, pp: 410.

40. Abd El Ghani MM (2000) Vegetation composition of Egyptian inland saltmarshes. Bot Bull Sin 41: 305-314.

41. Salem SM, Gammal ElSA (2018) Salt Minerals at Wadi El Natrun Saline Lakes, Egypt. New Implications from Remote Sensing Data. European Chemical Bulletin 7(2): 72-80.

42. El Sheikh MA, Abbadi GA (2004) Biodiversity of plant communities in the Jal Az-Zor National Park, Kuwait. Kuwait J Sci Eng 31(1): 77-105.

43. Salama FM, Ahmed MK, El-Tayeh NA, Hammad SA (2012) Vegetation analysis, phenological patterns and chorological affinities in Wadi Qena, Eastern desert, Egypt. Afr J Ecol 50(2): 193-204.

44. Wang KF, Han XB (1983) Study on the Cenozoic fossil Concentricystes in East China (in Chinese). Acta Palaeontol Sin 22: 468-473.

45. Bader J, Dallmeyer A, Claussen M (2017) Theory and Modeling of the African Humid Period and the Green Sahara. Oxford Research Encyclopedia of Climate Science.

46. Hoelzmann P, Holmes J (2017) The Late PleistoceneHolocene African Humid Period as Evident in Lakes. Oxford Research Encyclopedia of Climate Science.

47. Dawelbeit A, Jaillard E, Eisawi A (2019) Sedimentary and paleobiological records of the latest PleistoceneHolocene climate evolution in the Kordofan region, Sudan. Journal of African Earth Sciences 160: 103-605.

48. Rossignol M (1962) Analysis pollinique de Sediments marin quaternnires en Israel.II Sediments Plleistocenes, Pollen et Spores 4(1): 121-184.

49. Rossignol M (1969) Sedimentation palynologique dans la domaine Marin quaternaire de Palestine: etude de paleoenvironment, Notes et Mem. Orient X Nature Paris, pp: 272.

50. Saad SI, Sami S (1967) Studies of pollen and spores content of the Nile Delta deposits (Berenbal Region). Pollen ET Spores, pp: 476-503.

51. Hong B, Liu CQ, Lin QH, Yasuyuki S, Leng XT, et al. (2009) Temperature evolution from the $\delta^{18} 0$ record of Hani peat, Northeast China, in the last 14000 years. Science in China Series D Earth Sciences 52: 952-964.

52. Ritchie JC (1986) Modern pollen spectra from Dakhla Oasis, Western Egyptian Desert. Grana 25(3): 1-6.

53. Ayyad SM (1988) Pollen Grain Ecology of the Mediterranean Sea Coast Egypt, Thesis, Mansura University, Egypt, pp: 136-140.

54. El Shenbary SH (1985) A study of recent changes in vegetation composition in the North Western coastal desert of Egypt in Burg El-Arab area. Thesis, Tanta University, Egypt.

55. Mercuri AM (2008) Human influence plant landscape evolution and climate inferences from the archaeobotanical records of the Wadi Teshuinat area (Libyan Sahara). J Arid Environ 72(10): 1950-1967.

56. Schultz E (1987) Die Holozane Vegetation der zentralen Sahara (N-Mali, N-Niger, and SW-Libyen) Palaeoecol Africa 18: 143-161.

57. Prach K (1994) Vegetation succession on river gravel bars across the Northwestern Himalayas, India. Arct Alp Res 26(4): 349-353.

58. Mehringer JR, Petersen KL, Hassan FA (1979) A pollen record from Birkket Qarun and the recent history of the Fayum, Egypt. Quaternary Research 11(2): 238-256.

59. Leps J, Rejmanek M (1991) Convergence or divergence: what should we expect from vegetation succession? Oikos 62: 261-264. 